Canadian

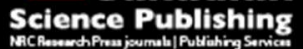

Botany

Botanique

\title{
Pollen morphology in selected species of Caricaceae with special reference to novel palynological characters
}

\begin{tabular}{|r|l|}
\hline Journal: & Botany \\
\hline Manuscript ID & cjb-2017-0125.R1 \\
\hline Manuscript Type: & Article \\
\hline Date Submitted by the Author: & 21-Sep-2017 \\
\hline Complete List of Authors: & $\begin{array}{l}\text { Zini, Lucía; Instituto de Botanica del Nordeste, } \\
\text { Carrera, Constanza; Consejo Nacional de Investigaciones Científicas y } \\
\text { Técnicas; Instituto de Fisiología y Recursos Genéticos Vegetales INTA-CIAP } \\
\text { Lattar, Elsa; Cátedra de Morfología de Plantas Vasculares, Facultad de } \\
\text { Ciencias Agrarias, Universidad del Nordeste } \\
\text { Ferrucci, María Silvia; Instituto de Botanica del Nordeste }\end{array}$ \\
\hline $\begin{array}{r}\text { Is the invited manuscript for } \\
\text { consideration in a Special } \\
\text { Issue? : }\end{array}$ & N/A \\
\hline Keyword: & Caricaceae, Carica, Jacaratia, Vasconcellea, Palynology \\
\hline & \multicolumn{2}{|c|}{} \\
\hline \multicolumn{2}{|c}{} \\
\hline
\end{tabular}




\section{Pollen morphology in selected species of Caricaceae with special reference to novel}

\section{palynological characters}

Lucía Melisa Zini $^{1,2,}{ }^{*}$, Constanza Soledad Carrera ${ }^{2,4}$, Elsa Clorinda Lattar ${ }^{1,3}$ and María Silvia Ferrucci $^{1,2,3}$

${ }^{1}$ IBONE-UNNE-CONICET. Corrientes, Argentina, Sargento Cabral N 2131, 3400.

${ }^{2}$ Consejo Nacional de Investigaciones Científicas y Técnicas.

${ }^{3}$ Cátedra de Morfología de Plantas Vasculares, Facultad de Ciencias Agrarias, Universidad del

Nordeste. Corrientes, Argentina, Sargento Cabral N² 2131, 3400.

${ }^{4}$ Instituto de Fisiología y Recursos Genéticos Vegetales INTA-CIAP, Córdoba, Argentina, 11 de Septiembre 4755 (X5020ICA).

* Corresponding autor: Lucía Melisa Zini ${ }^{1,2}$ (Sargento Cabral $N^{\circ} 2131,3400$, Corrientes, Argentina, email: zinimelisa@gmail.com)

Constanza Soledad Carrera ${ }^{2,4}$ (11 de Septiembre 4755, Córdoba, Argentina, email: carrera.coty@gmail.com),

Elsa Clorinda Lattar ${ }^{1,3}$ (Sargento Cabral No 2131, 3400, Corrientes, Argentina, email: elsilattar@gmail.com)

María Silvia Ferrucci ${ }^{1,2,3}$ (Sargento Cabral No 2131, 3400, Corrientes, Argentina, email: msferrucci@yahoo.com.ar). 
Abstract: The pollen grain morphology of Jacaratia corumbensis Kuntze, J. spinosa (Aubl.) A.DC., Vasconcellea quercifolia A. St.-Hil., and Carica papaya L. from Argentine samples were examined for the first time, using light and scanning electron microscopes. Observations and measurements were performed on acetolyzed pollen grains. Principal-components analysis was performed for quantitative morphological variables. Pollen grains were tri-colporate with lalongate endoaperture, oblate spheroidal to prolate, medium, exine bireticulate or reticulate, with granulate lumina. Fastigium was present. Novel palynological data in this study for species identification revealed the presence of margo in C. papaya and variations in endoaperture shapes in all the species. The endoaperture ends often were H-shaped or horn-shaped. The biplot showed a clear separation of the four taxa based on the palynological traits. V. quercifolia was strongly correlated with equatorial diameter, equatorial diameter in polar view, exine thickness, and polar diameter, whereas $J$. corumbensis and J. spinosa were positively correlated with polar index and polar area index, respectively. The distance between two colpi allowed the discrimination of $C$. papaya. We confirmed the homogenous nature for most of the qualitative palynological characters in Caricaceae, and demonstrated that pollen morphology in combination with statistical analyses is a reliable tool for delimiting taxonomic groups.

Key words: Caricaceae, Carica, Jacaratia, Vasconcellea, Palynology, endoaperture 


\section{Introduction}

Caricaceae Dumort. is a small family that belongs to the Brassicales order and comprises 6 genera and about 34 species of usually dioecious trees, shrubs or herbs (Carvalho et al. 2015; APG IV 2016). This family presents staminate flowers with a rudimentary pistil and pistillate flowers without vestiges of the androecium; in Carica L. perfect flowers are also present (Kubitzki 2003). The family is mostly Neotropical, distributed from Mexico to Argentina and Chile, with only two native species (Cylicomorpha Urb.) from Africa (Kubitzki 2003). The monotypic Carica papaya L. is the most economically important species of the family not only because it is used for its fruits crop, but also because it produces the enzyme papain, which is used in food and pharmaceutical industries (Carvalho et al. 2015). In Argentina, the species was introduced and cultivated for the production of fruits and candy elaboration. The genera native to this country are Jacaratia A. DC. and Vasconcellea A. St.-Hil. (Zuloaga et al. 2008). Vasconcellea species are also of increasing interest because of their properties potentially suitable for C. papaya improvement (Siar et al. 2011; Silva et al. 2012; d' Eeckenbrugge 2014). In the early taxonomic studies, Carica and Vasconcellea were treated as a single genus, but later both genera were rehabilitated (Badillo 1967, 1971, 2000). The most comprehensive molecular phylogeny of the family subsequently supported the monophyly of Vasconcellea confirming the phylogenetic distance with Carica and its relationship with Jacaratia, whereas Carica is closely related to Jarilla Rusby and Horovitzia V.M. Badillo (Carvalho and Renner 2014).

Palynology is an important source of morphological information for the taxonomy, phylogenetic, and evolutionary trends of pollen in a wide range of angiosperm families. It is also important for studies on pollen preserved as fossil in sediments or archaeological sites, and for characterization of the botanical composition and geographical origin of honeys (Erdtman 1952; Walker and 
Doyle 1975; Barth et al. 2004; Pire et al. 2004; Doyle 2005; Sodré et al. 2007; Wortley et al. 2015). In recent studies, pollen grains analyzed in honey samples were identified as belonging to Carica and Vasconcellea (Flores and Sánchez 2010; Sánchez and Lupo 2011; Barth et al. 2013). Even though the species exhibit phalaenophilous syndrome (Bawa 1980), bees harvesting pollen from staminate flowers, have been reported (Piratelli et al. 1998; Cerino et al. 2015; Dey et al. 2016). Regarding palynological studies, Erdtman (1952) was the first author to describe the pollen grains of C. papaya and Jacaratia mexicana A. DC. Badillo (1971) reported some pollen characters in species of Cylicomorpha, Jacaratia, Jarilla, and Vasconcellea. Fisher (1980), Silva Santos et al. (2008) and Phuangrat et al. (2013) mentioned a few pollen features for C. papaya regarding exine sculpture, infratectum structure, and aperture type. Sandoval Sierra et al. (2006) studied quantitative and qualitative morphological characters of the pollen grains in C. papaya and in 6 of 21 species of Vasconcellea. The latter study revealed that the polar and equatorial axes, and polar area were valuable taxonomic characters for the distinction of both genera. In addition, the previously cited studies revealed morphological variability of the pollen grains within $C$. papaya. Nevertheless, pollen studies in Caricaceae are still scarce, possibly due to the small size of the family and the fact that slight palynological variations were observed (Erdtman 1952; Badillo 1971).

Given the significance of palynological information and its systematization in different research fields, the aim of this study was to investigate for the first time the pollen grain morphology in Jacaratia corumbensis Kuntze, J. spinosa (Aubl.) A.DC., and Vasconcellea quercifolia A. St.Hil., and in the $C$. papaya samples from Argentina. The taxonomic value of pollen morphological attributes was verified. 


\section{Materials and methods}

\section{Plant material}

The pollen material was obtained from mature staminate floral buds of herbarium specimens deposited at the Instituto de Botánica del Nordeste herbarium (Table 1).

\section{Pollen morphological analyses}

Pollen morphology was studied using light microscopy (LM) and scanning electron microscopy (SEM). The pollen grains were acetolyzed according to the methodology of Erdtman (1966). The samples were mounted in glycerin jelly and the slides were then deposited in the pollen herbarium of the National University of the Northeast (PAL-CTES). Measurements and photographs were obtained with a Leica DM LB2 (Leica, Wetzlar, Germany) light microscope. For SEM analyses, the acetolyzed pollen grains were mounted on a metal stub and coated with 20 nm of gold-palladium. Microphotographs were obtained with a Jeol JSM-5800LV (JEOL USA, Peabody, MA, USA) scanning electron microscope.

The terminology used to describe pollen grains follows that of Punt et al. (2007). The quantitative traits were: equatorial diameter $(\mathrm{E})$, polar diameter $(\mathrm{P})$, polar index $(\mathrm{PI})$, equatorial diameter in polar view (EP), exine thickness (Ex), distance between two colpi in polar view (DC), polar area index (PAI), endoaperture length (EnL), and endoaperture width (EnW). For each species, measurements were made on 30 pollen grains from two or three specimens. To measure the endoaperture size, the widest diameter was considered. The pollen shapes are determined according to the ratio between the polar axis and equatorial diameter (Punt et al. 2007). Polar area indices were calculated as the ratio between distance between two colpi and equatorial diameter in polar view $(\mathrm{DC} / \mathrm{EP})$.

\section{Statistical analyses}


Descriptive statistics (range of variation and mean values) were performed for the quantitative variables related to measurements of pollen grains obtained with LM. Principal component analysis (PCA) was used to explore associations between the set of morphological variables and the four taxa analyzed. Statistical differences between the four taxa were determined by ANOVA at a $5 \%$ significance level $(p \leq 0.05)$ for the evaluated morphological variables. When ANOVA test indicated significant differences $(p \leq 0.05)$, means were compared using the Fischer LSD test. All calculations were made using the statistical software Infostat (Di Rienzo et al. 2011).

\section{Results}

\section{General features}

Pollen grains were tri-colporate, isopolar, radiosymmetric, oblate spheroidal to prolate, medium sized (22-42 $\mu \mathrm{m}$ in diameter), circular or lobate amb. The colpi (1-2 $\mu \mathrm{m}$ in width) were narrow and the endoapertures were lalongate, with elliptic contour and acute ends. The endoaperture end was usually split or projected longitudinally toward the two poles (H-shaped or similar) or curved towards one of the poles (horn-shaped). However, the limit of the endoapertures were not always clearly visible. A fastigium was present. The exine was tectate or semi-tectate, columellate, 1-3 $\mu \mathrm{m}$ thick; the sexine was thicker than or as thick as the nexine. The sculpturing was reticulate or bireticulate, with ornate lumina. Microperforations were present on the mesocolpium, apocolpium, and the apertural region. The lumina or depressions were generally microgranulate. The colpus membrane was microgranulate.

Pollen morphology descriptions of each species

Carica papaya (Fig. 1A-E, Fig. 3A-C)

Oblate spheroidal to prolate spheroidal, circular amb. $\mathrm{P}=32-40 \mu \mathrm{m}, \mathrm{E}=30-37 \mu \mathrm{m}, \mathrm{P} / \mathrm{E}=0.94-$ 1.13. Exine 1-2.5 $\mu \mathrm{m}$ thick; sexine $1-2 \mu \mathrm{m}$, nexine $0.5-1 \mu \mathrm{m}$. Endoaperture predominantly 
rectangular, devoid of equatorial constriction, 6-11 $\times 3-6 \mu \mathrm{m}$. Endoaperture with narrow longitudinal. Under SEM, the exine was reticulate or bireticulate, heterobrochate, with irregular lumina generally of $1 \mu \mathrm{m}$ or more in diameter. The muri were psilate. Apocolpium with microperforations and a few reticulae. The area surrounding the ectoaperture was psilate with microperforations, constituting a margin or margo of approximately 3-4 $\mu \mathrm{m}$ width, which was distinguishable under LM and SEM.

Jacaratia corumbensis (Fig. 1F-J, Fig. 2A, Fig. 3D-F)

Prolate spheroidal to prolate, lobate amb. $\mathrm{P}=29-38 \mu \mathrm{m}, \mathrm{E}=22-32 \mu \mathrm{m}, \mathrm{P} / \mathrm{E}=1.09-1.7$. Exine 1-3 $\mu \mathrm{m}$ thick; sexine $0.75-1.5$, nexine $0.25-0.5$. Elliptic endoaperture slightly constricted or not, acute ends, H-shaped endoaperture or with longitudinal projections parallel to the colpi which extend to the distal pole, $12-17 \times 2-5 \mu \mathrm{m}$. Under SEM, the exine was reticulate or bireticulate on the mesocolpium; depressions were $\leq 1 \mu \mathrm{m}$. Mesocolpium and apocolpium with microperforations.

Jacaratia spinosa (Fig. 1K-O, Fig. 2B-D, Fig. 3G-I)

Oblate spheroidal to subprolate, subcircular amb. $\mathrm{P}=30-39, \mathrm{E}=27-33 \mu \mathrm{m}, \mathrm{P} / \mathrm{E}=0.93-1.26$. Exine 1-2 $\mu \mathrm{m}$ thick; sexine 1-1.5, nexine $0.25-1$. Elliptic endoaperture generally with equatorial constriction and acute ends or H-shaped, 10-16 × 3-7 $\mu \mathrm{m}$. Under SEM, the exine was reticulate or bireticulate at the mesocolpium. Microperforations were present in both the mesocolpium and apocolpium.

Vasconcellea quercifolia (Fig. 1P-T, Fig. 3J-L)

Oblate spheroidal to prolate spheroidal, sub-circular or sub-triangular amb, angulaperturate. $\mathrm{P}=$ $35-50, \mathrm{E}=34-42, \mathrm{P} / \mathrm{E}=0.97-1.33$. Exine $1.50-3 \mu \mathrm{m}$ thick; sexine $1.5-2$ nexine $0.5-1$. Elliptic endoaperture with equatorial constriction, acute ends or occasionally split ends, $12-19 \times 2-6 \mu \mathrm{m}$. 
Under SEM, the exine was reticulate or bireticulate. Microperforations were present in both the apertural region and apocolpium.

\section{Statistical analysis}

The mean values of the pollen morphological variables were compared in Table 2 . The ranges of variation were 32-50 $\mu \mathrm{m}$ for $\mathrm{P}, 22-42 \mu \mathrm{m}$ for E, 1.0-3.0 $\mu \mathrm{m}$ for Ex, 6-19 $\mu \mathrm{m}$ for EnW, and 25-45 $\mu \mathrm{m}$ for EP, with $V$. quercifolia exhibiting the highest mean value and $J$. corumbensis the lowest, except for EnW with $C$. papaya exhibiting the lowest value. PI raged from 0.93 to 1.70 , with $J$. corumbensis and C. papaya exhibiting the highest and lowest mean value, respectively. The variables EnL and DC ranged between 2.0 and $7.0 \mu \mathrm{m}$, and 7.0 and $19 \mu \mathrm{m}$, respectively. Carica papaya and J. spinosa showed the highest mean values for EnL, whereas $V$. quercifolia showed the lowest value. For DC, C. papaya and J. corumbensis presented the highest and the lowest mean value, respectively. The range of variation of PAI was similar for C. papaya, $J$. corumbensis, and $J$. spinosa the three species with the highest value. Vasconcellea quercifolia presented the lowest mean value of PAI.

A multivariate analysis was carried out to explore correlations between pollen morphological variables and the four taxa analyzed. The biplot obtained from the first two principal components (PC1 and PC2) explained $97.6 \%$ of the total variability in the data (Fig. 4), and showed that E, EP, Ex, P, and PAI were the morphological variables of greatest variation among the studied species, and exhibited the highest correlation with the first axis. The main correlations with the second axis were obtained for PI, EnL, DC and EnW, with the last two exhibiting the highest correlation with this axis. The biplot in the first axis indicated that of all the studied species, $V$. quercifolia was positively correlated with E, EP, Ex, and P, and explained $58.8 \%$ of the total data variability. Jacaratia corumbensis and J. spinosa were placed on the opposite side of the axis; 
PAI and PI contributed to their separation since J. spinosa was positively correlated with PAI, whereas $J$. corumbensis was positively correlated with PI. Along the second axis of the biplot, which displayed $38.8 \%$ of the variation of the data, C. papaya was positively correlated with DC (Fig. 4).

Significant differences were observed among the four species for all the quantitative morphological variables analyzed (Table $3 p<0.05$ ). V. quercifolia differed from the other three species in seven (P, E, PI, Ex, EnW, EP, PAI) of the nine variables, followed by J. corumbensis with six variables (P, E, PI, Ex, EnW, EP), whereas C. papaya and J. spinosa were distinguished from the rest of the species by five variables (E, PI, EnW, DC, EP). It is noteworthy, that $V$. quercifolia exhibited the highest mean value for P, E, Ex, EnW, EP, and the lowest for PAI. The remaining species did not differ among them in PAI. The highest PI was recorded in $J$. corumbensis and the highest DC mean value was observed in C. papaya.

\section{Discussion}

In agreement with previous studies in Caricaceae, the pollen grains of C. papaya, J. corumbensis, J. spinosa and V. quercifolia (van der Hammen 1952; Erdtman 1966; Badillo 1971; LudlowWiechers 1981; Sandoval Sierra et al. 2006) are tri-colporate with lalongate endoapertures, and spheroidal to prolate in shape; the exine is tectate collumelate, perforate, reticulate or bireticulate, and lumina and colpus membrane are granulate. Also in agreement with previous studies, the pollen grains of the Caricaceae species studied are of medium size. Phuangrat et al. (2013) analyzed the pollen diameter of perfect and staminate flowers in C. papaya (non-acetolyzed samples and measurements from SEM images), and did not find larger pollen size or significant differences between flowers morphs. However, Sandoval Sierra et al. (2006) reported large pollen grains in acetolyzed samples of $C$. papaya $(50-52 \mu \mathrm{m})$. In contrast with the present study, 
the latter authors indicated that spheroidal shape is absent in C. papaya and Vasconcellea. Although it is not mentioned in the article by Phuangrat et al. (2013), the SEM pollen photomicrographs in that work reveal the presence of a margo in the examined samples of $C$. papaya. Accordingly, variability of pollen grains among different specimens of C. papaya concerns shape, size, and distinction of the margo; therefore, these slight variations should be considered for pollen identification in this species.

The present study confirms the typical lalongate aperture found in Caricaceae, and adds that the endoapertures can exhibit $\mathrm{H}$ shape, slightly branch ends, or markedly split ends into narrow projections directed toward the two distal poles (seen in polar view as refractive striae surrounding the colpus). All possible shapes were present even in a single sample of Jacaratia species. However, besides the typical lalongate aperture, only the more elaborated endoaperture was observed in C. papaya, and only endoapertures with split ends were present in $V$. quercifolia. In other angiosperm families, both a lalongate horn-shaped endoaperture and a margin are present in some Primulaceae (Carrion et al. 1993). A margin, lalongate endoaperture, and reticulate sculpture are present together in pollen grains of the Fabaceae species (Luz et al. 2013). The $\mathrm{H}$ endoaperture was defined by Punt and Nienhuis (1976) as a composite endoaperture, consisting of a central part which connects two lateral, longitudinally elongated legs, thus forming an H. These legs may be short or long. This type of endoaperture was also reported in other families, such as Cornaceae, Gentianaceae, and Rubiaceae (Punt et al. 2007; Kuang et al. 2008). Additionally, quite similar longitudinal endoaperture projections to those found in LM images of Carica and Jacaratia seem to be present in Qualea Aubl. and Vochysia Aubl. (Vochysiaceae); these structures were described as large grooves devoid of nexine limiting a great 
apertural area (Barth and Luz 2014). The range of variation in endoapertures is noteworthy for Caricaceae, and is probably rare or with an underreported occurrence among angiosperms.

The multivariate analysis clearly showed that the four taxa were distinguishable based on specific pollen morphological traits. PAI and PI contributed to the differentiation between $J$. corumbensis and J. spinosa, respectively; distinguish J. corumbensis from J. spinosa, respectively, DC allowed the discrimination of C. papaya, and E, EP, Ex, and P of V. quercifolia.

Based on the studied material, pollen have characters of strong diagnostic value to discriminate species of Carica, Jacaratia, and Vasconcellea. Those features include equatorial axis, polar index, endoaperture width and apocolpium size (distance between two colpi) and are useful for species determination. According to Sandoval Sierra et al. (2006), Vasconcellea species [ $V$. cauliflora (Jacq.) A.DC., V. cundinamarcensis V.M.Badillo, V. crassipetala V.M.Badillo, V. goudotiana Triana \& Planch., V. longiflora V.M.Badillo, and V. sphaerocarpa (García-Barr. \& Hern.Cam.) V.M.Badillo, are separated from C. papaya mainly by polar and equatorial axis values, and by polar area. In the current study, the nine palynological traits tested were important to discriminate $C$. papaya from the studied species of Vasconcellea.

The distinction of both genera can be determined using palynological features, thus supporting the phylogenetic distance between Carica and Vasconcellea, as revealed by recent molecular phylogenetic studies (Carvalho and Renner 2014).

\section{Conclusions}

A range of endoaperture shapes in the Caricaceae species as well as the presence of margo in pollen grains of Carica papaya are reported for the first time in the family. Therefore, these are new characters of diagnostic value for species identification. Indeed, the present study confirms that even though Caricaceae is a stenopalynous family, the palynological traits together with 
statistical analyses of quantitative variables is a reliable tool for determining the taxonomic groups. Future studies in Caricaceae should integrate palynology with genetic data, such as genome size and chromosome number, as well phylogeny to arrive at stronger conclusions about the systematic implication of the palynological traits.

\section{Acknowledgements}

Financial support for this research was provided by the Agencia Nacional de Promoción Científica, Tecnológica y de Innovación, Argentina (ANPCyT-UNNE, PICTO 2012-0202), and by the Universidad Nacional del Nordeste (PI A012-2013). M.S. Ferrucci and C.S. Carrera are members of CONICET, the Scientific Research Council of Argentina.

\section{References}

APG IV. 2016. An update of the angiosperm phylogeny group classification for the orders and families of flowering plants: APG IV. Bot. J. Linn. Soc. 181: 1-20. doi: 10.1111/boj.12385

Badillo, V.M. 1967. Esquema de las Caricaceaes. Agron. Trop. 17: 245-271.

Badillo, V.M. 1971. Monografía de la familia Caricaceae. Asoc Prof Univ Centr Venezuela. pp.221.

Badillo, V.M. 2000. Carica L. vs. Vasconcella St.-Hil. (Caricaceae) con la rehabilitación de este último. Ernstia, 10: 74-79.

Barth, O.M., and Luz, C.F.P. 2014. Pollen morphology of Vochysiaceae tree species in the state of Santa Catarina, Southern Brazil. Rev. Biol. Trop. 62: 1209-1215.

Barth, O.M, Barreto, C.F, Coelho, L.G., and Luz, C.F.P. 2004. Pollen record and paleoenvironment of a 4210 years B.P. old sediment in the Bay of Guanabara, Rio de Janeiro, Brazil. An. Acad. Bras. Cienc. 76: 549-551. doi: 10.1590/S0001-37652004000300009 
Barth, O.M, Freitas, A.S, Almeida-Muradian, L.B., and Vit, P. 2013. Palynological analysis of Brazilian stingless bee pothoney. In Stingless bees process honey and pollen in cerumen pots: Facultad de Farmacia y Bioanálisis. Edited by P. Vit and D.W. Roubik. Universidad de Los Andes, Mérida, Venezuela. pp. 1-8.

Bawa, K.S. 1980. Mimicry of male by female flowers and intrasexual competition for pollinators in Jacaratia dolichaula (D.Smith) Woodson (Caricaceae). Evolution, 34: 467-474. doi: 10.1111/j.1558-5646.1980.tb04836.x

Carrion, J.S, Delgado, M.J, and Garcia, M. 1993. Pollen grain morphology of Coris (Primulaceae). Plant Syst. Evol. 184: 89-100. doi: 10.1007/BF00937780

Carvalho, F.A, and Renner, S.S. 2014. The phylogeny of the Caricaceae. In Genetics and genomics of papaya, Plant genetics and genomics, crops and models. Edited by R. Ming and P.H. Moore. Springer, New York, USA. pp. 81-92. doi: 10.1007/978-1-4614-8087-7_5

Carvalho, F.A., Filer, D., and Renner, S.S. 2015. Taxonomy in the electronic age and an emonograph of the papaya family (Caricaceae) as an example. Cladistics, 31: 321-329. doi: 10.1111/cla. 12095

Cerino, M.C., Torretta, J.P., Gutiérrez, H.F., Richard, G.A., and Pensiero, J.F. 2015. Reproductive biology of Vasconcellea quercifolia A.St.-Hil. (Caricaceae), a moth-pollinated 'highland papaya'. Plant Syst. Evol. 301: 589-598. doi: 10.1007/s00606-014-1097-6

d'Eeckenbrugge, G.C., Drew, R., Kyndt, T., and Scheldeman, X. 2014. Vasconcellea for papaya improvement. In Genetics and genomics of papaya, Plant genetics and genomics, crops and models. Edited by R. Ming and P.H. Moore. Springer, New York, USA. pp. 47-79. doi: 10.1007/978-1-4614-8087-7_4 
Dey, K., Mondal, S., and Mandal, S. 2016. Flower-visitor diversity with reference to pollen dispersal and pollination of Carica papaya L. Int. J. Adv. Res. Biol. Sci. 3: 65-71.

Di Rienzo, J.A, Casanoves, F., Balzarini, M.G, Gonzalez, L., Tablada, M., and Robledo, C.W. 2011. InfoStat version 2011. Córdoba: Universidad Nacional de Córdoba, Retrieved from http://www.infostat.com.ar (accessed 8 June 2016).

Doyle, J.A. 2005. Early evolution of angiosperm pollen as inferred from molecular and morphological phylogenetic analyses. Grana, 44: 227-251. doi: 10.1080/00173130500424557

Erdtman, G. 1952. Pollen morphology and plant taxonomy-Angiosperms: an introduction to palynology. Vol I, Almqvisit \& Wiksell, Stockholm; pp.539.

Erdtman, G. 1966. Pollen morphology and plant taxonomy. Angiosperms. Hafner Publ. Co., New York; pp. 553.

Fisher, J.B. 1980. The vegetative and reproductive structure of papaya (Carica papaya). Lyonia, 1:191-208.

Flores, F.F., and Sánchez, A.C. 2010. Primeros resultados de la caracterización botánica de mieles producidas por Tetragonisca angustula (Apidae, Meliponinae) en Los Naranjos, Salta, Argentina. Bol. Soc. Argent. Bot. 45: 81-91.

Kuang, Y., Kirchoff, B.K, Tang, Y., Liang, Y., and Liao, J. 2008. Palynological characters and their systematic significance in Naucleeae (Cinchonoideae, Rubiaceae). Rev. Palaeobot. Palynol. 151:123-135. doi: 10.1016/j.revpalbo.2008.03.003

Kubitzki, K. 2003. Caricaceae. In Flowering Plants-Dicotyledons. Edited by K. Kubitzki and C. Bayer. Springer Berlin Heidelberg. pp. 57-61.

Ludlow-Wiechers, B. 1981. Catálogo palinológico para la flora de Veracruz. N4. Familia Caricaceae. Biotica, 6: 33-42. 
Luz, C.F, Maki, E.S, Horak-Terra, I., Vidal-Torrado, P., and Mendonca Filho, C.V. 2013. Pollen grain morphology of Fabaceae in the Special Protection Area (SPA) Pau-de-Fruta, Diamantina, Minas Gerais, Brazil. An. Acad. Bras. Cienc. 85: 1329-1344. doi: 10.1590/0001-3765201380511 Phuangrat, B., Phironrit, N., Son-ong, A., Puangchon, P., Meechai, A., Wasee, S., Kositratana, W., and Burns, P. 2013. Histological and morphological studies of pollen grains from elongata, reduced elongata and staminate flowers in Carica papaya L. Trop. Plant Biol. 6: 210-216. doi: $10.1007 / \mathrm{s} 12042-013-9118-0$

Piratelli, A.J, Piña-Rodrigues, F.C.M., Gandara, F.B, Santos, E.M.G., and Costa, L.G.S. 1998. Biologia da polinização de Jacaratia spinosa (Aubl) ADC. (Caricaceae) em mata residual do sudeste brasileiro Rev. Bras. Biol. 58: 671-679.

Pire, S.M., Anzótegui, L.M., and Cuadrado, G.A. 2004. Estudios palinológicos en el litoral fluvial argentino. Miscelánea, 12: 139-146.

Punt, W., and Nienhuis, W. 1976. Gentianaceae. Rev. Palaeobot. Palynol. 21(2): 89-123. doi: 10.1016/0034-6667(76)90018-X

Punt, W., Blackmore, S., Nilsson, S., and Le Thomas, A. 2007. Glossary of pollen and spore terminology. Rev. Palaeobot. Palynol. 143: 1-81. doi: 10.1016/j.revpalbo.2006.06.008

Sánchez, A.C., and Lupo, L.C. 2011. Origen botánico y geográfico de las mieles de El Fuerte, Departamento de Santa Bárbara, Jujuy, Argentina. Bol. Soc. Argent. Bot. 46: 105-111.

Sandoval Sierra, C.L., Caetano, C.M., Lagos, T.C., and Chávez-Servia J.L. 2006. Palinología de Carica y Vasconcellea (Caricaceae). Acta Agron. 55: 33-38. doi: 10.15446/acag

Siar, S.V., Beligan, G.A, Sajise, A.J.C., Villegas, V.N., and Drew, R.A. 2011. Papaya ringspot virus resistance in Carica papaya via introgression from Vasconcellea quercifolia. Euphytica, 181: 159-168. doi: 10.1007/s10681-011-0388-z 
Silva, E.N.D., Freitas Neto, M., Pereira, T.N., and Pereira, M.G. 2012. Meiotic behavior of wild Caricaceae species potentially suitable for papaya improvement. Crop Breed. Appl. Biotechnol. 12: 52-59. doi: 10.1590/S1984-70332012000100007

Silva Santos, L.M., Santana Pereira, T.N., Magalhães de Souza, M., Damasceno, P.C., da Costa, F.R., Ferreira Ribeiro, B., Gomes de Freitas, N., and Gonzaga Pereira, M. 2008. Optical and ultrastructural study of the pollen grain development in hermaphrodite papaya tree (Carica papaya L.). Braz. Arch. Biol. Technol. 51: 539-545. doi: 10.1590/S1516-89132008000300013

Sodré, G da S., Marchini, L.C., de Carvalho, C.A.L. and de C.C Moreti, A.C. 2007. Pollen analysis in honey samples from the two main producing regions in the Brazilian northeast. An. Acad. Bras. Cienc. 79: 381-388. doi: 10.1590/S0001-37652007000300003

van der Hammen, T. 1952. Informe sobre la colección de placas de polen reciente que ha sido preparado en el laboratorio del departamento de palinología. Servicio Geológico Nacional. Colombia; pp. 38 .

Walker, J.W., and Doyle, J.A. 1975. The bases of angiosperm phylogeny: palynology. Ann. Mo. Bot. Gard. 62: 664-723. doi: 10.2307/2395271

Wortley, A.H., Wang, H., Lu, L., Li, D.Z., and Blackmore, S. 2015. Evolution of Angiosperm pollen. 1. Introduction 1. Ann. Mo. Bot. Gard. 100: 177-226. doi: 10.3417/2012047

Zuloaga, F.O, Morrone, O., and Belgrano, M.J. 2008. Catálogo de las plantas vasculares del Cono Sur (Argentina, sur de Brasil, Chile, Paraguay y Uruguay) Vol II: Dicotiledoneae (Acanthaceae-Fabaceae). Monogr. Syst. Bot. Mo. Bot. Gard. USA. pp. 985. 
Table 1. Specimens examined and voucher information

\begin{tabular}{lll}
\hline Species & Voucher & Collection \\
\hline Carica papaya L. & Keller 1864 (CTES) & Paraje Paraíso, San Pedro, Misiones, Argentina \\
& Keller 1881 (CTES) & San Ignacio, Misiones, Argentina \\
Jacaratia corumbensis & Schulz 15840 (CTES) & Sáenz Peña, Chaco, Argentina \\
Kuntze & Pedersen 15832 (CTES) & Rosario de la Frontera, Salta, Argentina \\
& & \\
J. spinosa (Aubl.) A.DC. & Keller 9285 (CTES) & San Isidro Labrador, Iguazú, Misiones, Argentina \\
& Keller 7737 (CTES) & Complejo Club del Río, San Ignacio, Misiones, Argentina \\
& & \\
Vasconcellea quercifolia & Tressens et al. 3430 (CTES) & Rincón Santa María, Ituzaingó, Corrientes, Argentina \\
& Tressens 3622 (CTES) & Carlos Pellegrini, Mercedes, Corrientes, Argentina \\
A. St.-Hil. & Keller and Franco 5712 (CTES) & Aldea Yraka Miri, Concepción, Misiones, Argentina \\
\hline
\end{tabular}


Table 2. Pollen grain measurements in species of Carica, Jacaratia and Vaconcellea (minimum, maximum and mean values the latter inside parentheses)

\begin{tabular}{|c|c|c|c|c|c|c|c|c|c|}
\hline Species & $P^{*}$ & $\mathbf{E}^{*}$ & PI & $\mathbf{E x} *$ & EnL & EnW* & DC* & EP* & PAI \\
\hline C. papaya & $\begin{array}{c}32.0-40.0 \\
(35.8)\end{array}$ & $\begin{array}{c}30.0-37.0 \\
(34.3)\end{array}$ & $\begin{array}{c}0.94-1.13 \\
(1.04)\end{array}$ & $\begin{array}{l}1.0-2.0 \\
(1.77)\end{array}$ & $\begin{array}{c}3.0-6.0 \\
(4.93)\end{array}$ & $\begin{array}{c}6.0-11.0 \\
(9.17)\end{array}$ & $\begin{array}{c}9.0-19.0 \\
(13.23)\end{array}$ & $\begin{array}{c}32.0-40.0 \\
(35.97)\end{array}$ & $\begin{array}{c}0.24-0.50 \\
\quad(0.36)\end{array}$ \\
\hline $\begin{array}{l}J . \\
\text { corumbensis }\end{array}$ & $\begin{array}{c}29.0-38.0 \\
(33.7)\end{array}$ & $\begin{array}{c}22.0-32.0 \\
(26.4)\end{array}$ & $\begin{array}{c}1.09-1.70 \\
(1.28)\end{array}$ & $\begin{array}{c}1.0-3.0 \\
(1.55)\end{array}$ & $\begin{array}{c}2.0-5.0 \\
(3.97)\end{array}$ & $\begin{array}{c}12.0-17.0 \\
(14.83)\end{array}$ & $\begin{array}{c}7.0-13.0 \\
(9.97)\end{array}$ & $\begin{array}{c}25.0-32.0 \\
(27.40)\end{array}$ & $\begin{array}{c}0.28-0.46 \\
(0.36)\end{array}$ \\
\hline J. spinosa & $\begin{array}{c}30.0-39.0 \\
(34.7)\end{array}$ & $\begin{array}{c}27.0-33.0 \\
(29.7)\end{array}$ & $\begin{array}{c}0.93-1.26 \\
(1.17)\end{array}$ & $\begin{array}{c}1.0-2.0 \\
(1.75)\end{array}$ & $\begin{array}{c}3.0-7.0 \\
(4.90)\end{array}$ & $\begin{array}{c}10.0-16.0 \\
(13.03)\end{array}$ & $\begin{array}{c}10.0-15.0 \\
(11.22)\end{array}$ & $\begin{array}{c}29.0-32.0 \\
(30.47)\end{array}$ & $\begin{array}{c}0.31-0.48 \\
(0.36)\end{array}$ \\
\hline$V$. quercifolia & $\begin{array}{c}35.0-50.0 \\
(41.0)\end{array}$ & $\begin{array}{c}34.0-42.0 \\
(37.3)\end{array}$ & $\begin{array}{c}0.97-1.33 \\
(1.09)\end{array}$ & $\begin{array}{c}1.5-3.0 \\
(2.02)\end{array}$ & $\begin{array}{c}2.0-6.0 \\
(3.67)\end{array}$ & $\begin{array}{c}12.0-19.0 \\
(15.90)\end{array}$ & $\begin{array}{c}9.0-13.0 \\
(10.10)\end{array}$ & $\begin{array}{c}36.0-45.0 \\
(41.00)\end{array}$ & $\begin{array}{c}0.20-0.30 \\
(0.24)\end{array}$ \\
\hline
\end{tabular}


Table 3. Mean values of pollen morphological variables measured in C. papaya, J. corumbensis, $J$ spinosa and $V$. quercifolia

\begin{tabular}{lrrrr}
\hline Variables & C. papaya & J. corumbensis & J. spinosa & V. quercifolia \\
\hline Polar axis & $35.76^{\mathrm{b}}$ & $33.68^{\mathrm{a}}$ & $34.74^{\mathrm{b}}$ & $41.00^{\mathrm{c}}$ \\
Equatorial axis & $34.32^{\mathrm{c}}$ & $26.36^{\mathrm{a}}$ & $29.68^{\mathrm{b}}$ & $37.28^{\mathrm{d}}$ \\
Polar index & $1.04^{\mathrm{a}}$ & $1.28^{\mathrm{d}}$ & $1.17^{\mathrm{c}}$ & $1.09^{\mathrm{b}}$ \\
Exine thickness & $1.77^{\mathrm{b}}$ & $1.55^{\mathrm{a}}$ & $1.75^{\mathrm{b}}$ & $2.02^{\mathrm{c}}$ \\
Endoaperture length & $4.93^{\mathrm{b}}$ & $3.97^{\mathrm{a}}$ & $4.90^{\mathrm{b}}$ & $3.67^{\mathrm{a}}$ \\
Endoaperture width & $9.17^{\mathrm{a}}$ & $14.83^{\mathrm{c}}$ & $13.03^{\mathrm{b}}$ & $15.90^{\mathrm{d}}$ \\
Distance between two colpi & & & & \\
in polar view & $13.23^{\mathrm{c}}$ & $9.97^{\mathrm{a}}$ & $11.22^{\mathrm{b}}$ & $10.10^{\mathrm{a}}$ \\
Equatorial diameter & & & & \\
in polar view & $35.97^{\mathrm{c}}$ & $27.40^{\mathrm{a}}$ & $30.47^{\mathrm{b}}$ & $41.00^{\mathrm{d}}$ \\
Polar area index & $0.36^{\mathrm{b}}$ & $0.36^{\mathrm{b}}$ & $0.36^{\mathrm{b}}$ & $0.24^{\mathrm{a}}$ \\
\hline
\end{tabular}

Different superscript letters represent significant differences $(p<0.05)$ among species. 


\section{Figure captions}

Figure 1. LM photomicrographs of pollen grains. Carica papaya: A. Equatorial view. B. Colpus in equatorial view; note margins (asterisks) of a psilate appearance and detail of rectangular endoaperture contour. C. Mesocolpium ornamentation. D. Polar view. E. Apocolpium and colpi margo. Jacaratia corumbensis. F. Equatorial view. G. Colpus in equatorial view. H. Aperture in sub-equatorial view, with bifurcated endoaperture end. I. Polar view. J. Apocolpium. Jacaratia spinosa. K. Equatorial view. L. Aperture with bifurcated endoaperture end. M. Mesocolpium. N. Polar view. O. Apocolpium sculpture. Vasconcellea quercifolia. P. Equatorial view. Q. Colpus in equatorial view and endoaperture with constriction. R. Mesocolpium. S. Polar view. T. Apocolpium sculpture. Scale bars $=20 \mu \mathrm{m}$.

Figure 2. LM photomicrographs of pollen grains and endoapertures in Jacaratia. J. corumbensis: A. Lateral equatorial view of $\mathrm{H}$ endoaperture (arrows), with upper bifurcation (upper arrow). $J$. spinosa: B. Endoaperture extending parallel to the colpi and surrounding it at the distal pole (arrows). C. Lateral equatorial view of a horn-like endoaperture (arrow). D. Lateral equatorial view of elaborated endoaperture (arrows). Scale bars $=20 \mu \mathrm{m}$.

Figure 3. SEM photomicrographs of the pollen grains. Carica papaya: A. Equatorial view and detail of exine at mesocolpium. B. Polar view; note margin around each colpus. C. Detail of the aperture and perforate exine. Jacaratia corumbensis: D. Equatorial view and detail of exine at mesocolpium. E. Polar view. F. Detail of the aperture and exine. Jacaratia spinosa: G. Equatorial view and exine at mesocolpium. H. Polar view. I. Detail of the aperture and exine. Vasconcellea 
quercifolia: J. Equatorial view and scabrate exine at mesocolpium. K. Polar view. L. Detail of the aperture and scabrate exine. Scale bars $=2 \mu \mathrm{m}(\mathrm{C}, \mathrm{F}, \mathrm{I}, \mathrm{L}) ; 5 \mu \mathrm{m}(\mathrm{A}, \mathrm{B}, \mathrm{D}, \mathrm{E}, \mathrm{G}, \mathrm{H}, \mathrm{J}, \mathrm{K})$.

Figure 4. Biplot showing relationships between pollen morphological variables (black circles) and the four taxa analyzed (grey triangles). See text for character abbreviations. 


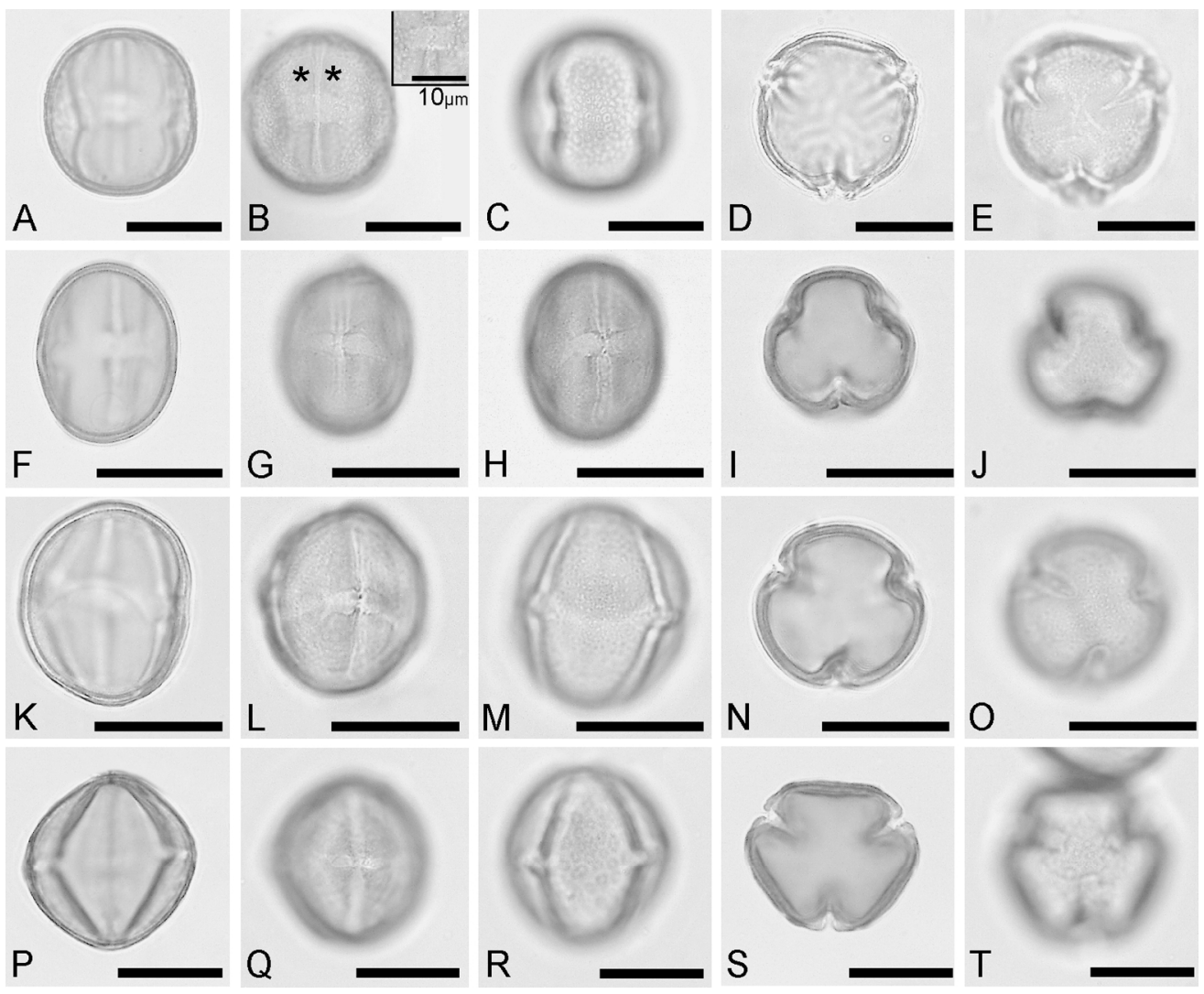

Figure 1. LM photomicrographs of pollen grains. Carica papaya: A. Equatorial view. B. Colpus in equatorial view; note margins (asterisks) of a psilate appearance and detail of rectangular endoaperture contour. C. Mesocolpium ornamentation. D. Polar view. E. Apocolpium and colpi margo. Jacaratia corumbensis. F.

Equatorial view. G. Colpus in equatorial view. H. Aperture in sub-equatorial view, with bifurcated endoaperture end. I. Polar view. J. Apocolpium. Jacaratia spinosa. K. Equatorial view. L. Aperture with bifurcated endoaperture end. M. Mesocolpium. N. Polar view. O. Apocolpium sculpture. Vasconcellea quercifolia. P. Equatorial view. Q. Colpus in equatorial view and endoaperture with constriction. R. Mesocolpium. S. Polar view. T. Apocolpium sculpture. Scale bars $=20 \mu \mathrm{m}$.

$138 \times 113 \mathrm{~mm}(300 \times 300 \mathrm{DPI})$ 

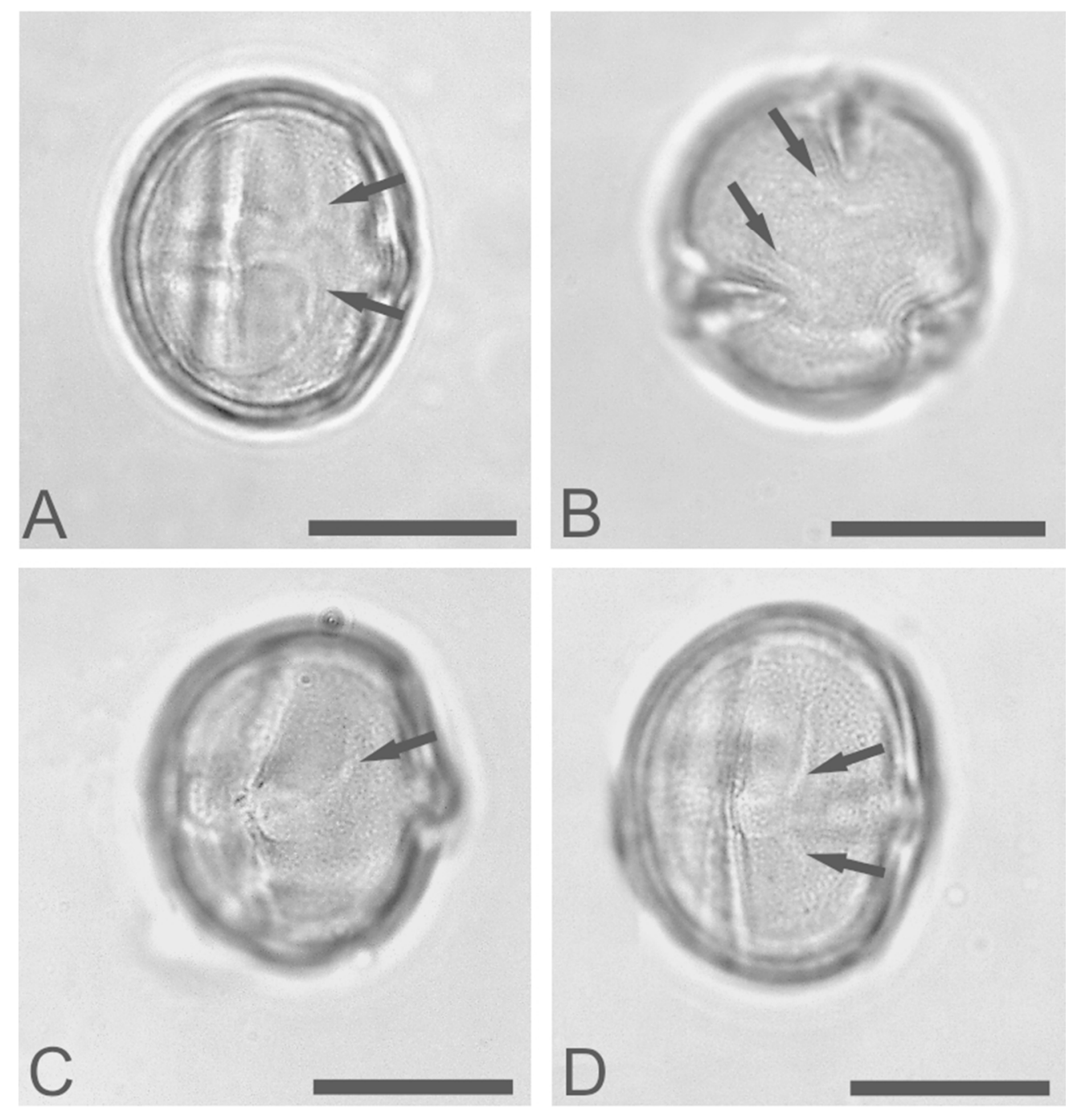

Figure 2. LM photomicrographs of pollen grains and endoapertures in Jacaratia. J. corumbensis: A. Lateral equatorial view of $\mathrm{H}$ endoaperture (arrows), with upper bifurcation (upper arrow). J. spinosa: B.

Endoaperture extending parallel to the colpi and surrounding it at the distal pole (arrows). C. Lateral equatorial view of a horn-like endoaperture (arrow). D. Lateral equatorial view of elaborated endoaperture (arrows). Scale bars $=20 \mu \mathrm{m}$.

$68 \times 71 \mathrm{~mm}(300 \times 300 \mathrm{DPI})$ 

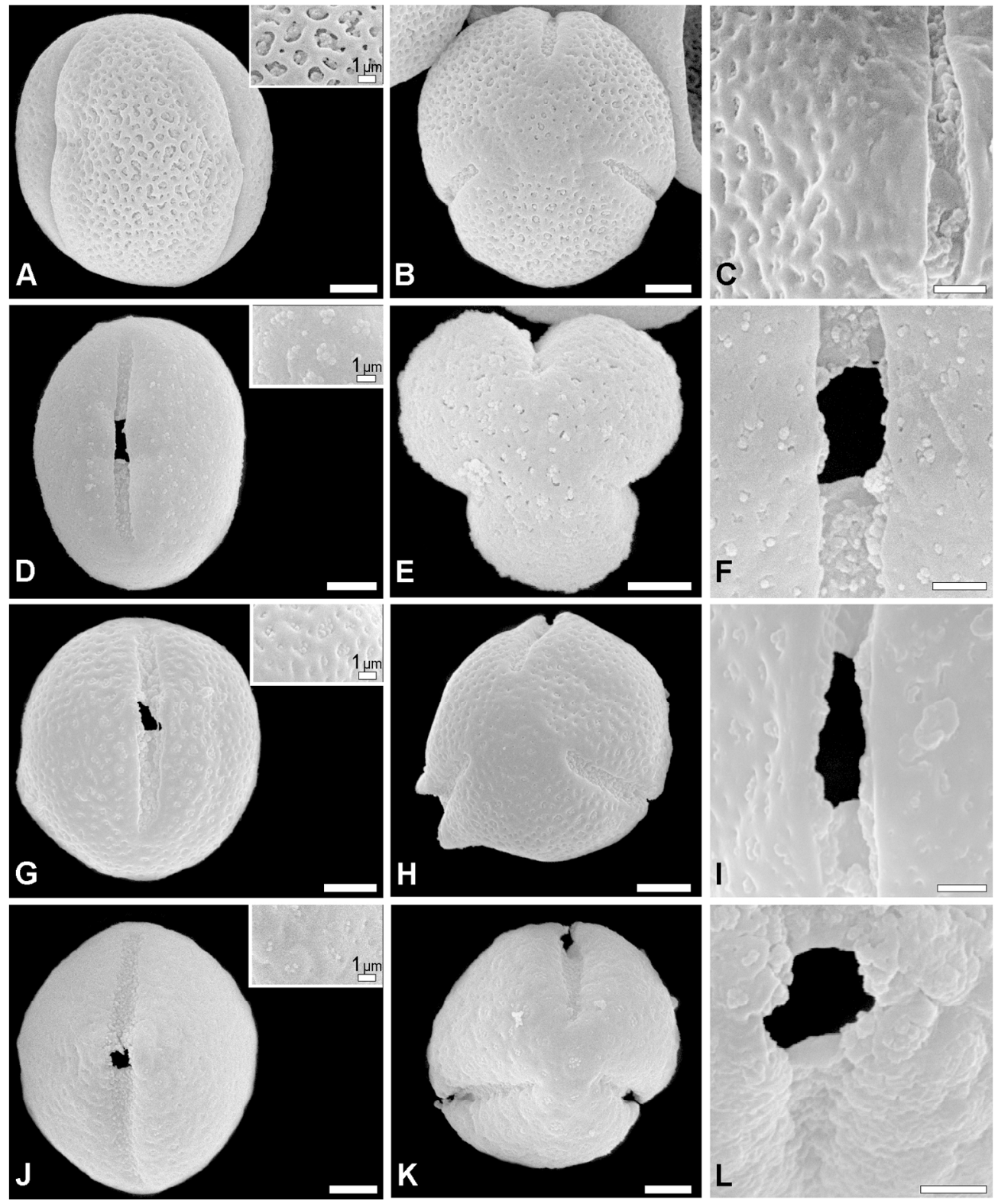

Figure 3. SEM photomicrographs of the pollen grains. Carica papaya: A. Equatorial view and detail of exine at mesocolpium. B. Polar view; note margin around each colpus. C. Detail of the aperture and perforate exine. Jacaratia corumbensis: D. Equatorial view and detail of exine at mesocolpium. E. Polar view. F. Detail of the aperture and exine. Jacaratia spinosa: G. Equatorial view and exine at mesocolpium. H. Polar view. I.

Detail of the aperture and exine. Vasconcellea quercifolia: J. Equatorial view and scabrate exine at mesocolpium. K. Polar view. L. Detail of the aperture and scabrate exine. Scale bars $=2 \mu \mathrm{m}(C, F, I, L) ; 5$ $\mu \mathrm{m}(A, B, D, E, G, H, J, K)$.

$137 \times 167 \mathrm{~mm}(300 \times 300 \mathrm{DPI})$ 


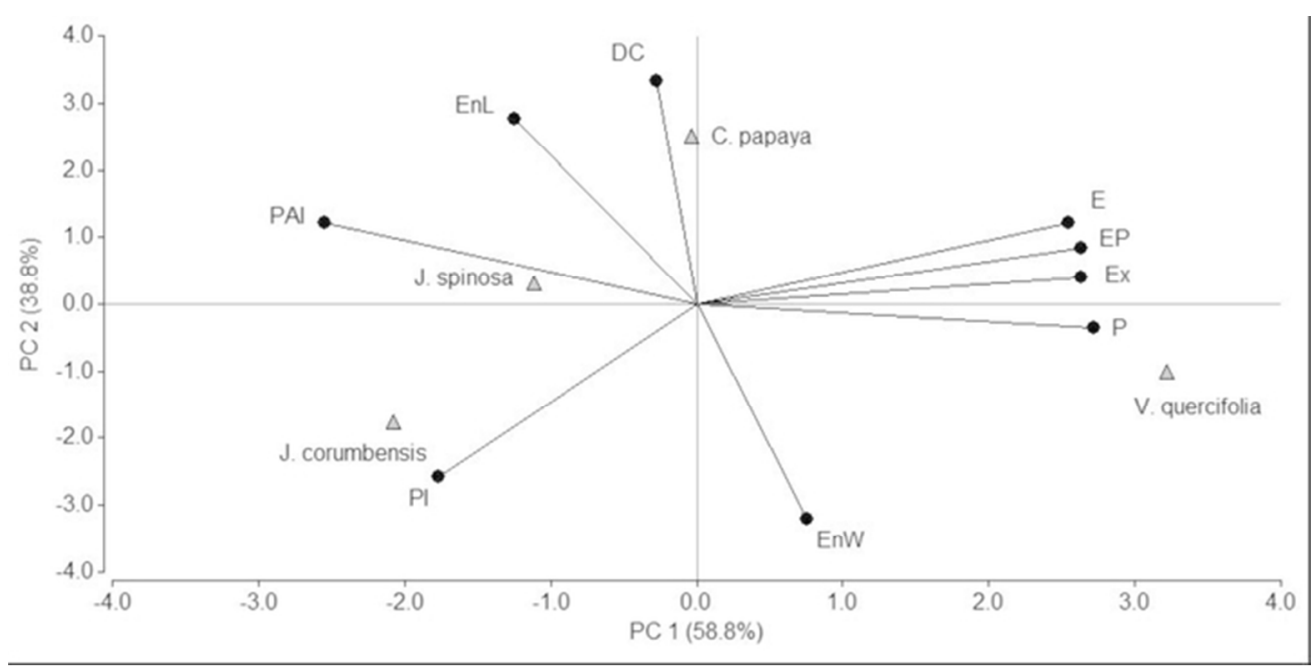

Figure 4. Biplot showing relationships between pollen morphological variables (black circles) and the four taxa analyzed (grey triangles). See text for character abbreviations.

$61 \times 30 \mathrm{~mm}(300 \times 300 \mathrm{DPI})$ 